Article

\title{
Long-Term Variation in the Tropospheric Nitrogen Dioxide Vertical Column Density over Korea and Japan from the MAX-DOAS Network, 2007-2017
}

\author{
Yongjoo Choi ${ }^{1, *(\mathbb{D}}$, Yugo Kanaya ${ }^{1}$, Hisahiro Takashima ${ }^{1,2} \mathbb{D}$, Hitoshi Irie ${ }^{3}$, Kihong Park ${ }^{4}$ and Jihyo Chong ${ }^{4,5}$ \\ 1 Research Institute for Global Change, Japan Agency for Marine-Earth Science and Technology, \\ Yokohama 236-0001, Japan; yugo@jamstec.go.jp (Y.K.); hisahiro@fukuoka-u.ac.jp (H.T.) \\ 2 Faculty of Science, Fukuoka University, Fukuoka 814-0133, Japan \\ 3 Center for Environmental Remote Sensing, Chiba University, 1-33 Yayoicho, Inage-ku, Chiba 263-8522, Japan; \\ hitoshi.irie@chiba-u.jp \\ 4 School of Earth Sciences and Environmental Engineering, Gwangju Institute of Science and Technology, \\ Gwangju 61005, Korea; kpark@gist.ac.kr (K.P.); jhchong1@korea.kr (J.C.) \\ 5 Environmental Management Division, Yeongsan River Basin Environmental Office, Gwangju 61945, Korea \\ * Correspondence: choingjoo@jamstec.go.jp; Tel.: +81-45-778-5860
}

check for updates

Citation: Choi, Y.; Kanaya, Y.; Takashima, H.; Irie, H.; Park, K.; Chong, J. Long-Term Variation in the Tropospheric Nitrogen Dioxide Vertical Column Density over Korea and Japan from the MAX-DOAS Network, 2007-2017. Remote Sens. 2021, 13, 1937. https://doi.org/ $10.3390 /$ rs13101937

Academic Editor: Francesca Barnaba

Received: 20 March 2021

Accepted: 13 May 2021

Published: 16 May 2021

Publisher's Note: MDPI stays neutral with regard to jurisdictional claims in published maps and institutional affiliations.

Copyright: (c) 2021 by the authors. Licensee MDPI, Basel, Switzerland. This article is an open access article distributed under the terms and conditions of the Creative Commons Attribution (CC BY) license (https:// creativecommons.org/licenses/by/ $4.0 /)$.

\begin{abstract}
We investigated long-term observations of the tropospheric nitrogen dioxide vertical column density ( $\mathrm{NO}_{2}$ TropVCD) from the Multi-Axis Differential Optical Absorption Spectroscopy (MAX-DOAS) network in Russia and ASia (MADRAS) from 2007 to 2017 at urban (Yokosuka and Gwangju) and remote (Fukue and Cape Hedo) sites in East Asia. The monthly mean in the $\mathrm{NO}_{2}$ TropVCD from MAX-DOAS measured at 13:30 local time, which is the Ozone Monitoring Instrument (OMI) overpass time, shows good agreement with OMI data during summer, but differences between the two datasets increase in winter. The Theil-Sen slope of the long-term trend indicate a relatively rapid and gradual reduction in $\mathrm{NO}_{2}$ at Yokosuka and two remote sites (Fukue and Cape Hedo), respectively, regardless of the season except for fall at Fukue, but significant changes in $\mathrm{NO}_{2}$ are not observed at Gwangju, Korea. In contrast, OMI satellite data reveal an increase in the $\mathrm{NO}_{2}$ TropVCD at all sites except for Yokosuka, where a decreasing trend common to MAX-DOAS is found, suggesting that the results from satellites need to be cautiously used for investigating long-term trends in less polluted or remote areas. Using backward trajectories, potential source regions are identified for the two urban sites. The spatial distribution from OMI data shows good agreement with the potential source regions at Yokosuka. The potential source regions in Gwangju are identified as the National Industrial Complex in Yeosu and Gwangyang, while the transport route is not clearly visible with OMI data because of their low sensitivity in less polluted areas. The proposed approach is suitable for identifying potential source areas that might not be recognized by satellite observations.
\end{abstract}

Keywords: nitrogen dioxide; MAX-DOAS; OMI; long-term trend; potential emission source

\section{Introduction}

Nitrogen oxides (NOx; i.e., $\mathrm{NO}$ and $\mathrm{NO}_{2}$ ) are emitted from natural (biomass burning and lightning) and anthropogenic (fossil fuel combustion) sources [1,2] and play an important role in global air pollution by acting as catalysts of ozone $\left(\mathrm{O}_{3}\right)$ formation in the troposphere and $\mathrm{O}_{3}$ destruction in the stratosphere [3]. Typically, under ultraviolet sunlight, $\mathrm{NO}_{2}$ produces $\mathrm{NO}$ and $\mathrm{O}\left({ }^{3} \mathrm{P}\right)$ through photolysis, and the produced $\mathrm{O}\left({ }^{3} \mathrm{P}\right)$ recombines with $\mathrm{O}_{2}$ to form $\mathrm{O}_{3}$. Then, the generated $\mathrm{O}_{3}$ reacts with $\mathrm{NO}$ again to generate $\mathrm{NO}_{2}$. The reaction cycle involving $\mathrm{NO}, \mathrm{NO}_{2}$, and $\mathrm{O}_{3}$ maintains an equilibrium state, the so-called photo-stationary state [4]. In addition, peroxy radicals $\left(\mathrm{HO}_{2}\right.$ and organic peroxy radicals, $\mathrm{RO}_{2}$ ), generated from the oxidation of volatile organic compounds (VOCs), react with $\mathrm{NO}$ to reproduce $\mathrm{NO}_{2}$, and then its photolysis generates $\mathrm{O}_{3}$, effectively increasing the ozone concentration [5]. This reaction simultaneously recycles $\mathrm{OH}$ radicals, thereby maintaining 
the concentration of peroxy radicals and determining the atmospheric oxidative capacity. Indeed, the reaction of $\mathrm{OH}$ radicals with $\mathrm{NO}_{2}$ during the daytime is the main pathway of nitric acid $\left(\mathrm{HNO}_{3}\right)$ formation and leads to the formation of ammonium nitrate $\left(\mathrm{NH}_{4} \mathrm{NO}_{3}\right)$, one of the main constituents of particulate matter, via gas-particle partitioning and/or heterogeneous reactions.

NOx emissions in China significantly increased due to rapid industrialization, economic growth, and urbanization during the two decades before the 2010s [6-8], but started to decrease in the early 2010s $[9,10]$ due to the effectiveness of China's Clean Air Action [11,12]. In particular, NOx emissions in eastern China from the Multi-resolution Emission Inventory for China (MEIC) decreased by 21\% in 2017 relative to 2013, which is a smaller decrease than the $30 \%$ decrease observed by the Ozone Monitoring Instrument (OMI) in $\mathrm{NO}_{2}$ columns over the same region during the same period [11]. Zheng et al. [11] also reported that ground-level $\mathrm{NO}_{2}$ concentrations for the same region and period decreased by only $9 \%$, which is significantly lower than the decreases in the NOx emissions and observations from OMI. The differences in the decreasing trends between OMI observations and surface $\mathrm{NO}_{2}$ might be mainly due to uncertainties in the satellite products - their uncertainties are large as they only assume vertical distributions of trace gases for the sensitivity calculations and need to assume horizontal homogeneity. Therefore, it is essential to validate satellite observations with ground-based observations of trace gases for accurate assessments not only on local and regional scales but also on a global scale.

For more than 20 years, Multi-Axis Differential Optical Absorption Spectroscopy (MAX-DOAS) measurements have been used to investigate aerosols and trace gases in the troposphere [13-16]. These passive remote sensing instruments measure the molecular absorption of scattered sunlight at several different viewing angles within the ultraviolet and visible spectral bands and then determine the tropospheric aerosol and trace gas concentrations by applying the DOAS technique. Ground-based MAX-DOAS has a higher sensitivity in the lower troposphere and a higher temporal resolution than satellite observations, thus enabling cost-effective investigations of tropospheric chemistry. Therefore, the tropospheric $\mathrm{NO}_{2}$ vertical column density $\left(\mathrm{NO}_{2}\right.$ TropVCD) determined from ground-based MAX-DOAS has been regarded as a ground truth and is suitable not only for evaluating those from satellite sensors, e.g., $[17,18]$, but also for investigating the temporal variation in the $\mathrm{NO}_{2}$ TropVCD at a local scale in both urban and rural areas [19-22].

As a part of the Global Earth Observation System of Systems (GEOSS)-related project, a long-term $\mathrm{NO}_{2}$ monitoring network based on MAX-DOAS over Russia and ASia (MADRAS; https:/ / ebcrpa.jamstec.go.jp/maxdoashp/(accessed on 20 December 2020)) was established by using a relatively cost-effective MAX-DOAS system [20]. The main purpose of our network observations is to retrieve the $\mathrm{NO}_{2}$ TropVCD (and its vertical profiles) during daytime and to validate satellite observations at several key locations with different levels of air pollution covering both urban and rural areas. The advantage of such networks is that data processing is standardized, thus ensuring a consistent quality of the data retrieved from the sites. In this study, we investigated $\mathrm{NO}_{2}$ TropVCD at four sites in East Asia (Yokosuka, Fukue, and Cape Hedo in Japan and Gwangju in Korea) during the period 2007-2017. The detailed temporal variations (hourly, monthly, and long-term) and potential emission sources of the $\mathrm{NO}_{2}$ TropVCD were investigated along with the temporal variations and spatial distribution from OMI satellite observations.

\section{Materials and Methods}

\subsection{Measurement Sites}

MAX-DOAS instruments were installed at four locations (Figure 1). Detailed geographical information, azimuth angles of the line of sight, and measurement periods for each instrument are summarized in Table 1. The Gwangju site $\left(126.84^{\circ} \mathrm{E}, 35.23^{\circ} \mathrm{N}\right)$ is located on the campus of the Gwangju Institute of Science and Technology (GIST) in southern 
Korea. As one of the metropolitan cities in Korea, the population of Gwangju within an area of $\sim 500 \mathrm{~km}^{2}$ is 1.5 million and a highway is located $1.5 \mathrm{~km}$ to the west of the site.

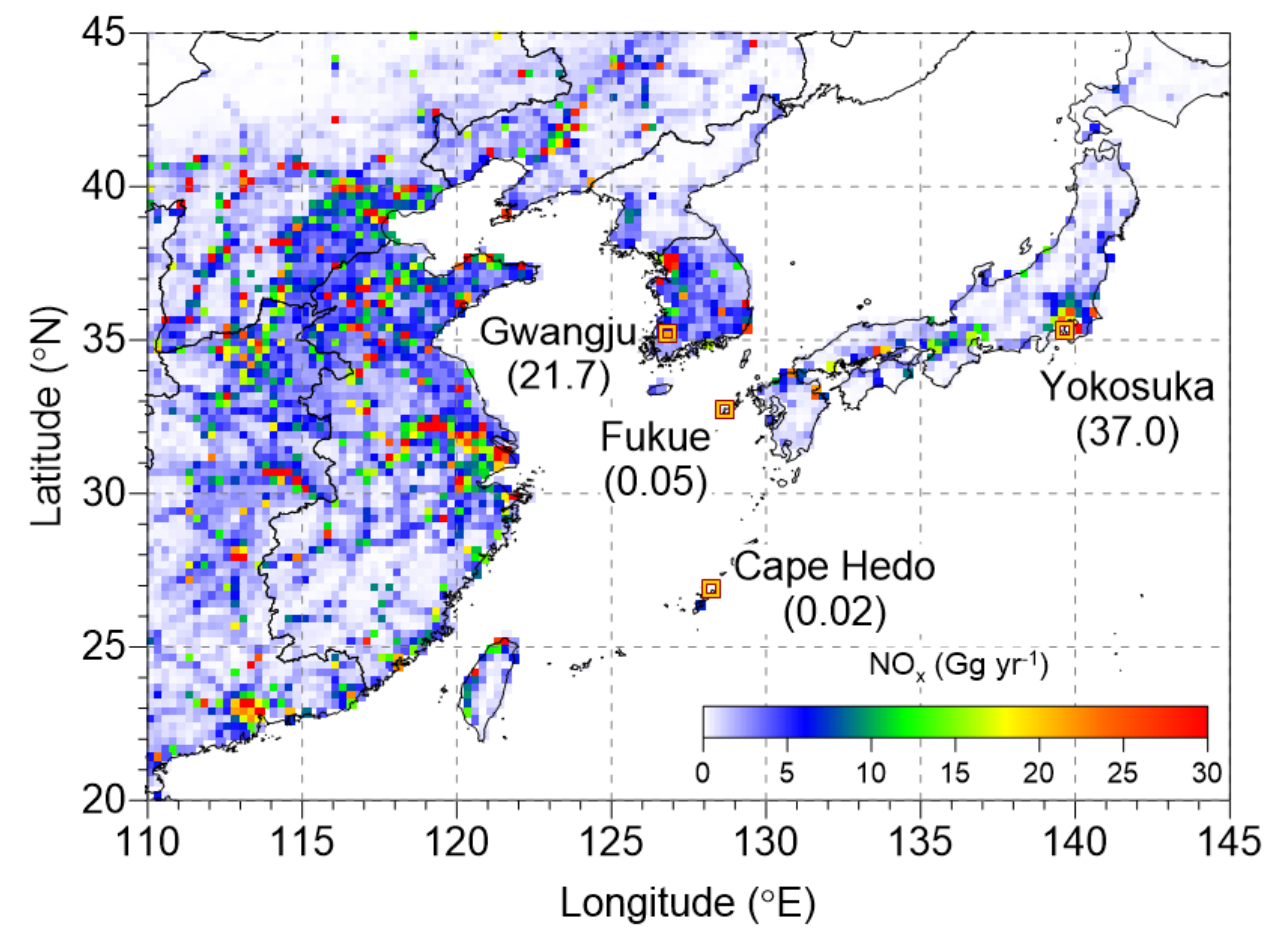

Figure 1. Emission rates of NOx $\left(\mathrm{Gg} \mathrm{yr}^{-1}\right)$ in the Regional Emission inventory in ASia (REAS) version 3.2 [12] over East Asia and site locations of selected MAX-DOAS networks (Gwangju in Korea and Yokosuka, Fukue, and Cape Hedo in Japan). The numbers in parentheses indicate the NOx emission rate of each site.

The Yokosuka site $\left(139.65^{\circ} \mathrm{E}, 35.32^{\circ} \mathrm{N}\right)$ is located within an industrialized area that extends in the north-south direction along Tokyo Bay in the Kanto Plain. The site is approximately $41 \mathrm{~km}$ south of the centre of Tokyo and $14 \mathrm{~km}$ south of the centre of Yokohama. The population of Yokosuka is only 0.41 million, but those of Tokyo (9.3 million) and Yokohama (3.7 million) are high, indicating a large influence of nearby local anthropogenic emissions from these larger cities at Yokosuka.

The Fukue site $\left(128.68^{\circ} \mathrm{E}, 32.75^{\circ} \mathrm{N}\right)$ is located on a peninsula of northwestern Fukue Island in the westernmost part of Kyushu, Japan [23-26]. The measurement site is remote and located approximately $20 \mathrm{~km}$ to the southeast of the main residential area, Goto (population of 38,000). Because Fukue is located between the Korean Peninsula ( $270 \mathrm{~km}$ from Busan, Korea) and Japan, it is a suitable place for monitoring the outflow from Korea and China.

Cape Hedo $\left(128.25^{\circ} \mathrm{E}, 26.87^{\circ} \mathrm{N}\right)$ is also a remote site and is located in the northernmost part of subtropical Okinawa Island $[20,27]$. There are no major emission sources around the site because it is distant not only from local cities ( $40 \mathrm{~km}$ from Nago, population of 60,000, and $100 \mathrm{~km}$ from Naha, population of 0.32 million), but also from the nearest major cities (more than $600 \mathrm{~km}$ from Shanghai, China; Taipei, Taiwan; and Fukuoka, Japan). Although the site is relatively close to a small city, Nago, the effect of anthropogenic emissions from Nago could be negligible since a national park and forests are located between Cape Hedo and Nago. 
Table 1. Detailed information of MAX-DOAS.

\begin{tabular}{cccccc}
\hline Site Name & Country & $\begin{array}{c}\text { Longitude } \\
\left({ }^{\circ} \mathbf{E}\right)\end{array}$ & $\begin{array}{c}\text { Latitude } \\
\left({ }^{\circ} \mathbf{N}\right)\end{array}$ & $\begin{array}{c}\text { Azimuth Angle } \\
\left({ }^{\circ} \text { from North, Clockwise) }\right.\end{array}$ & Periods \\
\hline Gwangju $^{\mathrm{a}}$ & Korea & 126.84 & 35.23 & 44 & $2008.2-2017.12$ \\
Yokosuka $^{\mathrm{b}}$ & Japan & 139.65 & 35.32 & 37 & $2007.10-2017.12$ \\
Fukue $^{\mathrm{a}}$ & Japan & 128.68 & 32.75 & 30 & Urban \\
Cape Hedo $^{\mathrm{b}}$ & Japan & 128.25 & 26.87 & -14 & $2009.2-2017.12$ \\
Remote \\
\hline
\end{tabular}

${ }^{a}$ rotating optical axes MAX-DOAS. ${ }^{b}$ fixed five-fold optical axes MAX-DOAS.

\subsection{MAX-DOAS Instruments}

The specifications of the MAX-DOAS instruments used in this study were described in detail in Kanaya et al. [20]. The MAX-DOAS instruments consist of a light-receiving part and a miniature spectrometer (USB4000; Ocean Optics, Dunedin, FL, USA) connected by a fibre optic cable bundle. Scattered sunlight (sky irradiance) collected by a telescope is redirected by a prism reflector and quartz fibre to the spectrometer for spectral analysis, with a field of view (FOV) of $<1^{\circ}$. From the measured wavelength range from 230 to $560 \mathrm{~nm}$, with less than $0.7 \mathrm{~nm}$ of the full-width at half-maximum (FWHM), we selected $460-490 \mathrm{~nm}$ for retrieving the $\mathrm{NO}_{2}$ and oxygen collision complexes $\left(\mathrm{O}_{2}-\mathrm{O}_{2}\right.$ or $\left.\mathrm{O}_{4}\right)$ column densities in this study. We installed MAX-DOAS systems for measuring the $\mathrm{NO}_{2}$ TropVCD with slightly different viewing azimuth angles depending on the site (mainly the north side; Table 1). By rotating a prism, the sky irradiance at six elevation angles (EAs; 3, 5, 10, 20,30 , and $90^{\circ}\left(70^{\circ}\right.$ for Cape Hedo)) was sequentially observed ( $5 \mathrm{~min}$ for each angle, for a total of $30 \mathrm{~min}$ ). For Yokosuka and Cape Hedo, the five-fold optical axes were installed for simultaneous observations at different EAs, but only a single telescope was used for sequential scanning for each EA. The measurements started in 2007 or later, with slight differences from site to site (Table 1). The longest measurement period was in Yokosuka and Cape Hedo at approximately 11 years (from 2007 to 2017), followed by that in Gwangju (10 years) and Fukue (9 years).

\subsection{Retrieval Algorithms}

All the measured spectra were retrieved following the same procedures to ensure consistent data quality among the sites. The algorithm consisted of DOAS spectral fittings using QDOAS software version 2.0 (http:/ / uv-vis.aeronomie.be/ software/QDOAS/, (accessed on 10 May 2020)) and conversion of differential slant column densities ( $\triangle$ SCDs) to the TropVCD by optimal estimation method [28]. Because a detailed description can be found in Kanaya et al. [20] and the references therein, we describe it here only briefly. All the measurement spectra were first corrected for offset and dark currents and analysed using the DOAS technique to retrieve the $\triangle \mathrm{SCD}$ of $\mathrm{O}_{4}$ and $\mathrm{NO}_{2}$ with respect to the reference spectrum (recorded with an EA of $90^{\circ}$ or $70^{\circ}$ within $30 \mathrm{~min}$ ). The $\triangle \mathrm{SCD}$ is defined as the difference in the slant column density (SCD) between the measured spectrum and the corresponding reference spectrum. The absorption by various species $\left(\mathrm{O}_{4}, \mathrm{NO}_{2}, \mathrm{O}_{3}\right.$, and $\mathrm{H}_{2} \mathrm{O}$ ) and the Ring effect [29] were considered. The cross sections included were $\mathrm{O}_{4}$ [30] but increased by a constant factor of 1.25 [31], $\mathrm{NO}_{2}$ at $298 \mathrm{~K}$ [32], $\mathrm{O}_{3}$ at $223 \mathrm{~K} \mathrm{[33],} \mathrm{H}_{2} \mathrm{O}$ [34]. A polynomial of degree three was used to fit the continuum.

MAX-DOAS profile inversion algorithms consisted of two steps. First, the aerosol extinction profiles below $5 \mathrm{~km}$ were retrieved and then used as constraints to retrieve the $\mathrm{NO}_{2}$ profile below $5 \mathrm{~km}$. To retrieve both the aerosol optical depth (AOD) at $476 \mathrm{~nm}$ and the $\mathrm{NO}_{2}$ TropVCD, an optimal estimation method [28] was applied to solve the nonlinear inversion problem with an iteration equation using a lookup table of box AMF that was generated by the Monte Carlo Atmospheric Radiative Transfer Simulator (MCARaTS; [35]). In brief, the state vector consisted of the target outputs (AOD or $\mathrm{NO}_{2}$ TropVCD) and three parameters $\left(f_{0-1 \mathrm{~km}}, f_{1-2 \mathrm{~km}}\right.$, and $f_{2-3} \mathrm{~km} ; f$ denotes the parameters determining the shape of a vertical profile of $\mathrm{AOD}$ or $\mathrm{NO}_{2}$ TropVCD and are defined to range between 0 and 1). Then, each partial column $(0-1,1-2$, and $2-3 \mathrm{~km})$ of the target outputs was 
expressed as $f_{0-1 \mathrm{~km}} \times$ output, $\left(1-f_{0-1 \mathrm{~km}}\right) \times f_{1-2 \mathrm{~km}} \times$ output, and $\left(1-f_{0-1 \mathrm{~km}}\right) \times(1-$ $\left.f_{1-2 \mathrm{~km}}\right) \times f_{2-3 \mathrm{~km}} \times$ output, respectively. A priori values of $f_{0-1 \mathrm{~km}}, f_{1-2 \mathrm{~km}}$, and $f_{2-3 \mathrm{~km}}$ were $0.60 \pm 0.05,0.80 \pm 0.03$, and $0.80 \pm 0.03$, respectively. The a priori values of the AOD and $\mathrm{NO}_{2}$ TropVCD were $0.21 \pm 3.0$ and $20 \%$ of the largest $\triangle S C D$ values for $\mathrm{NO}_{2}$ among the five $\triangle S C D$ s during $30 \mathrm{~min}$, respectively. The error covariance matrix of a priori values $\left(S_{a}\right)$ contains diagonal elements representing aforementioned uncertainties $\left(\mathrm{AOD}\right.$ or $\mathrm{NO}_{2}$, $f_{0-1 \mathrm{~km}}, f_{1-2 \mathrm{~km}}$, and $\left.f_{2-3 \mathrm{~km}}\right)$ and off-diagonal elements of zero [20].

A large fraction of cloud contaminated cases was eliminated in advance of $\mathrm{NO}_{2}$ retrievals, because we used only the cases where AOD were successfully retrieved from the measured $\mathrm{O}_{4}$ quantities at the five EAs [20]. The overall uncertainty (combined systematic and random uncertainties) in the AOD was estimated as 30\% from a comparison with the co-located sky radiometer and/or Mie LiDAR [36-38]. The overall uncertainty in the $\mathrm{NO}_{2}$ TropVCD was reported as $17 \%$, as it was influenced by random uncertainty $(\sim 10 \%$ based on the residuals in the $\triangle$ SCD fitting) and systematic uncertainty ( $14 \%$ due to the uncertainties in the AOD and AMF) [20]. The minimum detection limit (MDL) for the $\mathrm{NO}_{2}$ TropVCD at an altitude of $0-1 \mathrm{~km}$ was reported to be $<0.2 \mathrm{ppbv}$, corresponding to $5 \times 10^{14}$ molecules $\mathrm{cm}^{-2}[20,27,39]$. Quality control was carefully applied to remove data measured under unstable conditions (e.g., changes in integration time and temperature settings, large residuals in the spectral fittings and saturated signal levels) [20].

\subsection{Ozone Monitoring Instrument (OMI)}

The OMI is a UV/vis (ultraviolet/visible) passive nadir viewing satellite-borne imaging spectrometer onboard the National Aeronautics and Space Administration (NASA) Aura satellite launched in 2004 on a sun-synchronous orbit. The swath width of OMI is $2600 \mathrm{~km}$, thus enabling global daily coverage with high spatial resolution (up to $13 \mathrm{~km} \times$ $24 \mathrm{~km}$ ). We used the satellite-retrieved $\mathrm{NO}_{2}$ TropVCD, which was obtained from OMNO2d (OMI/Aura $\mathrm{NO}_{2}$ Cloud-Screened Total and Tropospheric Column L3 Global Gridded $0.25^{\circ} \times 0.25^{\circ}$ ) version 3 [40]. The main criteria used in generating the OMNO2d data products included a solar zenith angle $<85^{\circ}$, terrain reflectivity $<30 \%$, and cloud fraction $<30 \%$ (for cloud-screened fields). The SCDs of $\mathrm{NO}_{2}$ are derived from a revised spectral fitting algorithm in the visible range $(402-465 \mathrm{~nm})$ using an iterative sequential algorithm, resulting in lower SCD values that are much closer to other models and satellites [41]. $\mathrm{OMI} \mathrm{NO} \mathrm{N}_{2}$ SCDs are also converted to VCDs by using an AMF, which is calculated using $\mathrm{NO}_{2}$ profiles simulated on the basis of monthly geographical climatology constructed from 4-year simulations using the Global Modeling Initiative (GMI) model [42]. It should be noted that results using OMNO2 level 2 which has finer resolution (spatial resolution of up to $13 \mathrm{~km} \times 24 \mathrm{~km}$ ) were insignificant different from OMNO2d. The monthly $\mathrm{NO}_{2}$ TropVCD from MAX-DOAS and OMI satellite reported a strong correlation with a high Pearson's $\mathrm{R}$ of 0.93 for six sites in MADRAS network, but OMI systematically underestimated the $\mathrm{NO}_{2}$ TropVCD compared to MAX-DOAS [20].

\subsection{Potential Source Regions}

To investigate the influence of the regional transport of $\mathrm{NO}_{2}$, the potential source regions of $\mathrm{NO}_{2}$ were identified using the Hybrid Single Particle Lagrangian Integrated Trajectory (HYSPLIT) model, version 4 [43]. Notably, we used European Centre for MediumRange Weather Forecasts (ECMWF) ERA5 data, which provide a much finer resolution of $0.25^{\circ} \times 0.25^{\circ}$, as the input for the HYSLPIT model instead of the Global Data Assimilation System $\left(\mathrm{GDAS} ; 1^{\circ} \times 1^{\circ}\right)$ to improve the accuracy of the airmass trajectories. The starting altitude and time were $500 \mathrm{~m}$ above ground level and three times a day (08:00, 12:00, and 16:00 LT), respectively. First, a regional grid domain divided into $0.125^{\circ}$ areas was generated within $4^{\circ} \times 4^{\circ}$ around the measurement sites. Second, each backward trajectory tagged with a measured $\mathrm{NO}_{2}$ TropVCD was assigned to an individual grid $\left(0.125^{\circ} \times 0.125^{\circ}\right)$ when the trajectory altitude was lower than $2.5 \mathrm{~km}$. Then, we averaged the $\mathrm{NO}_{2}$ TropVCD data in each grid to identify the potential source region. Since the $\mathrm{NO}_{2}$ concentration 
levels in the atmosphere can be determined by its relatively short lifetime and advection from emission sources, the $\mathrm{NO}_{2}$ TropVCD loss resulting from photochemical reactions was considered based on the age weighting factor $(W), \exp (-t / \tau)$, which was used in backward propagation [19]. Here, $\tau$ is the assumed lifetime of $\mathrm{NO}_{2}$, and $t$ represents the travelling time for the air mass. Since $\tau$ for $\mathrm{NO}_{2}$ has strong seasonal variability, we applied different seasonal $\tau$ cycles: $24 \mathrm{~h}$ for winter, $18 \mathrm{~h}$ for spring and fall, and $12 \mathrm{~h}$ for summer. The reason we selected $24 \mathrm{~h}$ for the $\mathrm{NO}_{2}$ lifetime in winter is that the $\mathrm{NO}_{2}$ TropVCD from the model $\left(9.1 \times 10^{15}\right.$ molecules $\left.\mathrm{cm}^{-2}\right)$ reported in Lee et al. [44] was slightly lower but closer to that from Gwangju in winter $\left(12.4 \times 10^{15}\right.$ molecules $\left.\mathrm{cm}^{-2}\right)$ than the other assumed lifetimes therein. Considering $\tau$ for $\mathrm{NO}_{2}$, the backward trajectories were calculated for a period twice as long as the assumed $\tau$ (i.e., $48 \mathrm{~h}$ for winter, $36 \mathrm{~h}$ for spring and fall, and $24 \mathrm{~h}$ for summer). Because the assumed lifetime is used for only the calculation of the age weighting factor [19], the uncertainty due to the different $\tau$ values was less than $\pm 30 \%$ when $\tau$ was $50 \%$ higher and lower, indicating no significant impact on our spatial distribution. This approach has been applied to derive regional and global emissions of long-lived atmospheric trace gases and aerosols from ground-based measurements $[19,45,46]$ because the weighting factor is useful when multiple trajectories overlap within a single grid point. In addition, to ensure statistical significance, we allowed the number of trajectories that passed a single grid cell to be higher than three.

\section{Results and Discussion}

\subsection{Monthly Variation in the $\mathrm{NO}_{2}$ TropVCD from MAX-DOAS and OMI}

Figure 2 shows the monthly variation in the $\mathrm{NO}_{2}$ TropVCD at the four sites during the study period. OMI NO $\mathrm{N}_{2}$ TropVCD was selected from the grid $\left(0.25^{\circ} \times 0.25^{\circ}\right)$ where each MAX-DOAS measurement site is located. To consider the temporal discrepancy between MAX-DOAS and OMI data, two types of monthly mean MAX-DOAS data were used: (1) time-matched data ( $\pm 30 \mathrm{~min}$ ) with OMI overpass time of 13:30 LT and (2) daily mean using whole data (regardless of the measurement time) because the photo-chemical reaction at 13:30 LT was active during the daytime. To ensure accurate statistics, daily means were calculated from individual data points when three or more data points were available during the daytime from 07:00-17:00 local time (LT) but varied depending on the length of local daytime. Monthly means were obtained from the daily points when five or more daily points were available.

The highest overall mean $\mathrm{NO}_{2}$ TropVCD from MAX-DOAS was observed at Yokosuka $\left(20.3 \times 10^{15}\right.$ molecules $\left.\mathrm{cm}^{-2}\right)$, followed by Gwangju $\left(9.99 \times 10^{15}\right.$ molecules $\left.\mathrm{cm}^{-2}\right)$, Fukue $\left(2.65 \times 10^{15}\right.$ molecules $\left.\mathrm{cm}^{-2}\right)$, and Cape Hedo $\left(0.89 \times 10^{15}\right.$ molecules $\left.\mathrm{cm}^{-2}\right)$. The order of $\mathrm{NO}_{2}$ TropVCD coincides with that of the population and local emission sources. The order of magnitude of OMI NO $\mathrm{N}_{2}$ TropVCD was the same as that from MAX-DOAS, but the monthly mean concentrations of OMI were lower by a factor of 1.7 than the time-matched MAX-DOAS and 2.0 than the whole MAX-DOAS data, respectively. The relative change between OMI and time-matched MAX-DOAS was also lowest (3.1\%) at Cape Hedo, but the difference increased at urban sites.

The monthly variation in the $\mathrm{NO}_{2}$ TropVCD measured by MAX-DOAS and OMI showed similar seasonal variations at all measurement sites, with high $\mathrm{NO}_{2}$ in winter and low $\mathrm{NO}_{2}$ in summer. In winter, the atmospheric lifetime of $\mathrm{NO}_{2}$ is longer because of the diminution of solar irradiance, which suppresses photochemical reactions $[19,20]$ along with higher emission rates from anthropogenic sectors (fossil fuel and biofuel combustion). The low $\mathrm{NO}_{2}$ in summer could be a result of efficient partitioning to $\mathrm{NO}$ via the faster photolysis rates of $\mathrm{NO}_{2}$ and efficient oxidation of $\mathrm{NO}_{2}$ by $\mathrm{OH}$. Notably, the monthly mean of the time-matched MAX-DOAS data was consistent with that of the whole MAXDOAS data during the cold season but was more similar to that of OMI satellite data as summer approached. This is because the time at which the satellite passed over the site ( 13:30 LT) corresponded to the most active photochemical reactions due to the high solar irradiance, especially in summer. This disagreement between the time-matched and 
whole MAX-DOAS data during summer was greater in the urban areas (Yokosuka and Gwangju), suggesting that the diurnal variations were more pronounced because of a large amount of local emissions (such as transportation and industry) in the urban compared to the remote areas. The differences in both the time-matched and whole MAX-DOAS data with OMI satellite data increased during the cold season. This may be attributed to the inhomogeneous spatial distribution of $\mathrm{NO}_{2}$ due to the increased emissions from local sources (e.g., heating) and / or the enhanced contribution of Chinese NOx emissions to the $\mathrm{NO}_{2}$ levels in Korea and Japan during winter along with the long lifetime of $\mathrm{NO}_{2}$ (Figure S1) [44]. For this reason, a careful approach is required to assess the monthly $\mathrm{NO}_{2}$ TropVCD in urban areas using OMI satellite data.

(a) Yokosuka

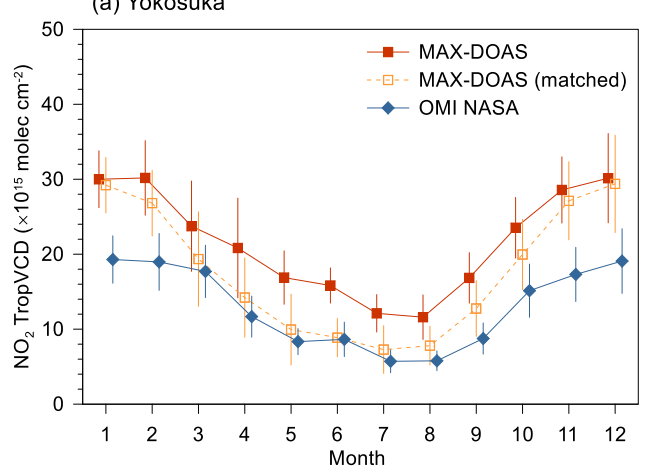

(c) Fukue

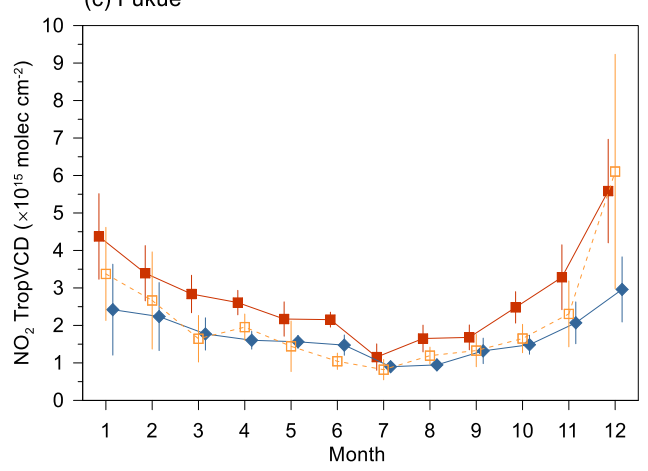

(b) Gwangju

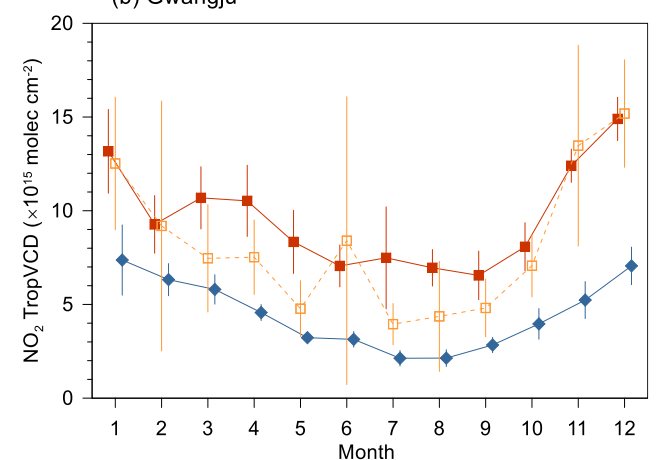

(d) Cape Hedo

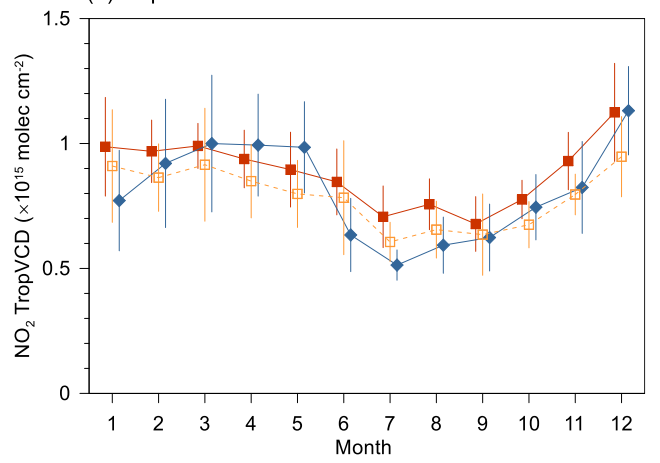

Figure 2. Monthly variation in $\mathrm{NO}_{2}$ TropVCD from MAX-DOAS and OMI at four sites: (a) Yokosuka, (b) Gwangju, (c) Fukue, and (d) Cape Hedo. Red and open orange squares indicate the mean of the whole and time-matched MAX-DOAS data with OMI satellite (blue diamonds) overpass time ( 13:30 local time). The vertical bars indicate the monthly standard deviation of $\mathrm{NO}_{2}$ TropVCD.

\subsection{Long-Term Trend in the $\mathrm{NO}_{2}$ TropVCD from OMI and MAX-DOAS}

Figure 3 shows the long-term trend in the $\mathrm{NO}_{2}$ TropVCD from time-matched MAXDOAS and OMI at the four sites with a linear Theil-Sen slope, which is used to analyse long-term temporal variations in air quality data because it is robust to outliers $[47,48]$. The Theil-Sen slope was calculated from the monthly means using the R function "TheilSen" included in the package "openair" in R cran [49]. Before calculating the Theil-Sen slope, the monthly mean was deseasonalized by decomposing into three parts (seasonal, trend, and residuals) using a 'Seasonal Trend decomposition using Loess' ("stl" function in the package "stats" which is also built into "openair"). 
(a) Yokosuka

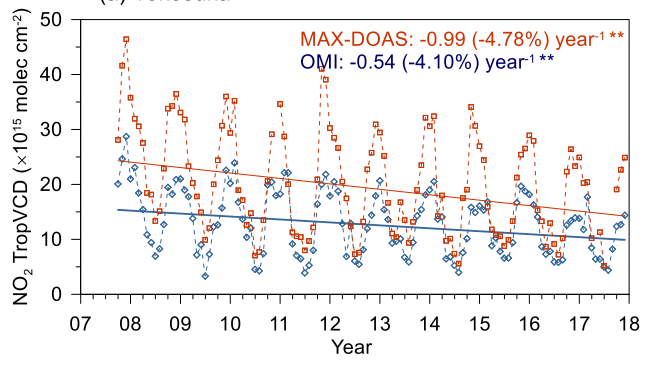

(c) Fukue

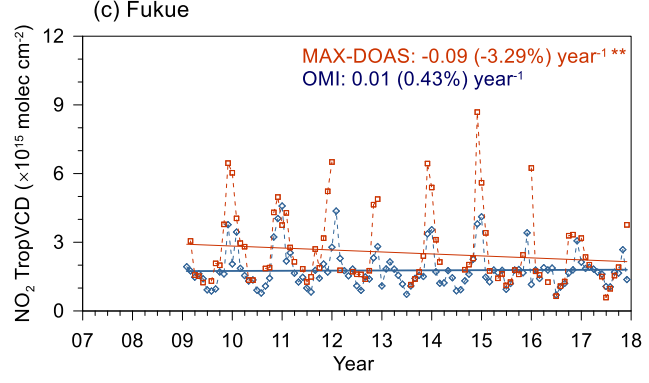

(b) Gwangju

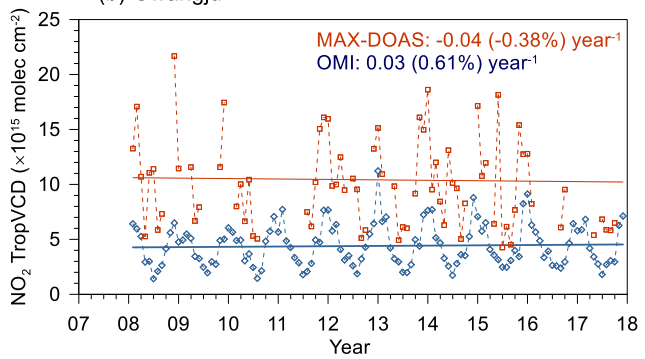

(d) Cape Hedo

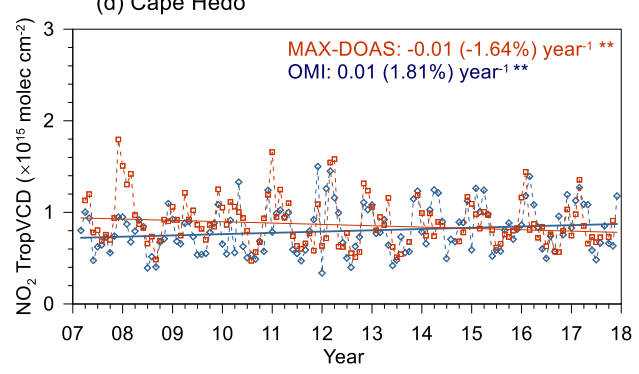

Figure 3. Long-term variations in the monthly mean of time-matched $\mathrm{NO}_{2}$ TropVCD from 2007 to 2017 at four sites. Red and blue symbols with solid lines denote the Theil-Sen slope for the MAX-DOAS and OMI satellite, respectively. The slopes and percent changes are shown in the upper right corner along with the $p$-value: ${ }^{* *} p<0.01,{ }^{*} p<0.05,+p<0.1$.

From 2007 to 2017, the $\mathrm{NO}_{2}$ TropVCD from time-matched MAX-DOAS in Japan (Yokosuka, Fukue, and Cape Hedo) continuously decreased by $-1.6 \% \mathrm{yr}^{-1}$ to $-4.8 \% \mathrm{yr}^{-1}$ at a significant level $(p<0.01$; Table 2$)$. The trends in Yokosuka from both MAX-DOAS and OMI are consistent with the decreasing $\mathrm{NO}_{2}$ TropVCD trend (from $-0.1 \pm 1.4 \% \mathrm{yr}^{-1}$ for Nagasaki to $-4.3 \pm 0.9 \% \mathrm{yr}^{-1}$ for Tokyo) from OMI observations $\left(0.1^{\circ} \times 0.1^{\circ}\right.$ by calculating an area-weighted average) from 2005-2014 based on the 2014 average $\mathrm{NO}_{2}$ TropVCD [50]. In addition, the ground $\mathrm{NO}_{2}$ concentration in the Tokyo metropolitan area also decreased from 2006 to 2012 [51], suggesting that ground-based and space-borne remote sensing instruments also captured the trend in ground $\mathrm{NO}_{2}$ concentrations in urban areas well.

In contrast, the $\mathrm{NO}_{2}$ TropVCD from MAX-DOAS in Gwangju did not undergo systematic changes $\left(-0.4 \% \mathrm{yr}^{-1}\right.$; ranging from -1.8 to $2.0 \% \mathrm{yr}^{-1}$ at the $95 \%$ confidence level), and the changes were insignificant ( $p \geq 0.1)$. The insignificant trend in Gwangju was also confirmed by reducing the time scale (2012-2015) when measurements were continuously conducted throughout the year $\left(-0.9 \% \mathrm{yr}^{-1}\right.$; ranging from -5.3 to $3.8 \%$ $\mathrm{yr}^{-1}$ at $95 \%$ confidence level and $\left.p \geq 0.1\right)$. The decreasing trend in Yokosuka $(-3.2 \%$ $\mathrm{yr}^{-1}$ with $\left.p<0.01\right)$ and constant trend in Gwangju $\left(-0.9 \% \mathrm{yr}^{-1}\right)$ are also confirmed by the ground-level $\mathrm{NO}_{2}$ concentration from the air quality monitoring stations near sites with similar trends from both time-matched and whole MAX-DOAS data (Table S1; Figure S2). Herman et al. [52] reported that the $\mathrm{NO}_{2} \mathrm{VCD}$ trend from the Pandora instrument (https:/ / pandora.gsfc.nasa.gov/Instrument/ (accessed on 13 August 2020)) in Gwangju significantly increased $\left(18 \% \mathrm{yr}^{-1}\right)$, but their study period was too short (approximately one year; May 2016 to July 2017) to estimate a long-term trend. Herman et al. [52] found a decreasing trend in both Seoul and Busan of approximately -3.8 and $-3.9 \% \mathrm{yr}^{-1}$ from 2012-2016, respectively. However, the ground-level NOx concentration in Seoul significantly decreased while the ground-level $\mathrm{NO}_{2}$ concentration remained constant [53], which was similar to that in Gwangju.

This finding might be explained by the air becoming more oxidative, which can rapidly convert $\mathrm{NO}$ to $\mathrm{NO}_{2}$, and/or by a contribution from the increased oxidation state of the NOx emitted from diesel vehicle emission control equipment (diesel particulate filters and diesel oxidation filters) as the fraction of diesel vehicles increased [53]. Moreover, the total number of registered diesel vehicles and their fraction of all registered vehicles increased 
gradually from 2011 to 2017 in both Seoul and Gwangju. Although the NOx emission rate decreased gradually in Japan and Korea after 2000, mainly due to a reduction in road transportation, the decrease in Japan was only remarkable because the total emission rate in Japan decreased by 52\% along with constant rates from domestic and industrial sectors, while that in Korea decreased by 9\% from 2007 to 2015 in the Regional Emission inventory in ASia (REAS) [12]. Compared to Yokosuka, where the percent of the decrease in the $\mathrm{NO}_{2}$ TropVCD from OMI satellite $\left(-4.1 \% \mathrm{yr}^{-1}\right)$ was similar to that from MAX-DOAS $(-4.8 \%$ $\mathrm{yr}^{-1}$ ), the trends in the $\mathrm{NO}_{2}$ TropVCD from OMI satellite at Fukue and Cape Hedo were opposite signs (increased with a significant level at Cape Hedo only) to those from MAXDOAS (decreased). These results suggest that a trend analysis using satellites might be appropriate for highly polluted urban areas because the less polluted and/or remote areas could be misdiagnosed the results from the implementation of atmospheric environmental regulations.

Table 2 shows the seasonal Theil-Sen slopes with $p$-values for the $\mathrm{NO}_{2}$ TropVCD from the time-matched MAX-DOAS and OMI satellite data. At the Japanese sites, all the seasonal trends except for the trend in fall at Fukue showed decreases, which was similar to the trend from whole MAX-DOAS data with a significant level $(p<0.05)$ (Table S1). The Theil-Sen slopes of the concentration in winter and percentage in spring were much steeper than those of other seasons. In particular, a rapid decrease was observed at Yokosuka. Considering that the seasonality driver of $\mathrm{NO}_{2}$ in the REAS emission inventory is the road transportation sector, whose emission rate was highest in spring and winter (mainly due to cold start emissions), the sharp decrease during these seasons could have resulted from a decrease in traffic volume (or mileage) and/or a decrease in the number of registered vehicles. Since the number of registered vehicles in 2017 was not much different (increased by 1.2\%) from that in 2007, the decrease in mileage due to the lower usage of vehicles might be a plausible reason for the pronounced decrease in spring and winter. However, the $\mathrm{NO}_{2}$ TropVCD at Gwangju increased in spring and autumn but sharply decreased in winter. Similar to that in Japan, the largest contributor to the $\mathrm{NO}_{2}$ TropVCD in Korea was the transportation sector. However, since 2007, (1) the number of registered vehicles in Korea has increased, (2) the mileage of vehicles and (3) the monthly variation in the traffic volume in Gwangju has remained constant (Traffic Monitoring System; http:/ / www.road.re.kr/main/main.asp (accessed on 15 July 2020)). Therefore, the influence of road transportation is not sufficient to explain the reduction in winter. Moreover, the ground-level $\mathrm{NO}_{2}$ measurements at nearby air quality monitoring sites (site P1 in Figure S3; $1.7 \mathrm{~km}$ to the west) also revealed a decreasing trend $\left(-0.7 \% \mathrm{yr}^{-1} ; p<0.01\right)$ that was similar but much lower in magnitude and occurred only in winter. This finding could be partially explained by the decreasing emissions in China, which have contributed to the $\mathrm{NO}_{2}$ abundance over Gwangju during winter because a relatively long $\mathrm{NO}_{2}$ lifetime was expected [44].

Table 2. Observed seasonal and overall Theil-Sen slopes of tropospheric $\mathrm{NO}_{2}$ vertical column density $\left(\mathrm{NO}_{2} \mathrm{TropVCD}\right.$ $\times 10^{15}$ molecules $\mathrm{cm}^{-2}$ ) from the time-matched MAX-DOAS and OMI satellite data at four sites from 2007-2017. ${ }^{\text {a }}$ The values in parentheses indicate the percentage of Theil-Sen slopes to the mean $\mathrm{NO}_{2}$ TropVCD corresponding time scale.

\begin{tabular}{|c|c|c|c|c|c|}
\hline & Spring & Summer & Fall & Winter & Overall \\
\hline \multicolumn{6}{|c|}{ (a) MAX-DOAS } \\
\hline Yokosuka & $-0.97(-5.92 \%)^{* *}$ & $-0.27(-2.54 \%)^{* *}$ & $-1.12(-4.77 \%)^{* *}$ & $-1.27(-4.14 \%)^{* *}$ & $-0.99(-4.78 \%)^{* *}$ \\
\hline Gwangju & $0.45(4.54 \%)^{* *}$ & $0.04(0.55 \%)$ & $0.39(4.43 \%)^{* *}$ & $-0.75(-5.31 \%)^{* *}$ & $-0.04(-0.38 \%)$ \\
\hline Fukue & $-0.22(-10.5 \%)^{* *}$ & $-0.03(-2.14 \%) *$ & $0.00(-0.22 \%)$ & $-0.38(-7.97 \%)^{* *}$ & $-0.09(-3.29 \%)^{* *}$ \\
\hline Cape Hedo & $-0.03(-3.34 \%) * *$ & $-0.01(-1.64 \%)^{* *}$ & $-0.01(-0.70 \%)^{* *}$ & $-0.01(-1.31 \%)^{* *}$ & $-0.01(-1.64 \%)^{\text {** }}$ \\
\hline \multicolumn{6}{|c|}{ (b) OMI satellite } \\
\hline Yokosuka & $-0.54(-4.50 \%) * *$ & $-0.15(-2.30 \%) * *$ & $-0.66(-4.62 \%)^{* *}$ & $-0.92(-4.79 \%)^{* *}$ & $-0.54(-4.10 \%) * *$ \\
\hline Gwangju & $0.01(0.16 \%)$ & $0.04(1.41 \%)^{* *}$ & $-0.01(-0.22 \%)$ & $0.11(1.65 \%)^{* *}$ & $0.03(0.61 \%)$ \\
\hline Fukue & $0.01(0.59 \%)+$ & $0.02(2.14 \%)^{* *}$ & $0.02(1.22 \%)+$ & $-0.11(-4.04 \%)^{* *}$ & $0.01(0.43 \%)$ \\
\hline Cape Hedo & $0.04(3.57 \%)^{* *}$ & $0.01(1.52 \%)^{* *}$ & $0.01(1.12 \%)^{* *}$ & $0.00(0.34 \%)^{* *}$ & $0.01(1.81 \%)^{* *}$ \\
\hline
\end{tabular}

$$
\mathrm{a} * * p<0.01, * p<0.05,+p<0.1 \text {. }
$$




\subsection{Diurnal Variation in the $\mathrm{NO}_{2} V C D$ below $1 \mathrm{~km}$ Altitude}

Because the lifetime of $\mathrm{NO}_{2}$ is short, the diurnal variations in urban $\mathrm{NO}_{2}$ concentrations are closely related to both human activities and photochemistry. Analysing the diurnal variation in the concentrations of atmospheric pollutants can provide further information on the composition of their emission sources and atmospheric processes involving primary and secondary sources. The mean normalized bias (MNB; $[\mathrm{A}-\mathrm{B}] / \mathrm{B} \times 100$, where $\mathrm{A}$ and $\mathrm{B}$ stand for hourly and daily mean $\mathrm{NO}_{2} \mathrm{VCD} 1 \mathrm{~km}$, respectively) for $\mathrm{NO}_{2}$ partial $\mathrm{VCD}$ for the lowest $1 \mathrm{~km}$ altitude range $\left(f_{0-1} \mathrm{~km} \times\right.$ TropVCD, hereafter termed $\left.\mathrm{NO}_{2} \mathrm{VCD} 1 \mathrm{~km}\right)$ in each month are shown in Figure 4. Typically, the $\mathrm{NO}_{2}$ concentration in urban areas increases because of stronger traffic emissions in the early morning and decreases because of effective partitioning to $\mathrm{NO}$ during daytime via $\mathrm{NO}_{2}$ photolysis and stronger oxidation of $\mathrm{NO}_{2}$ by $\mathrm{OH}$ in conjunction with increasing solar irradiance. Therefore, the diurnal variation in $\mathrm{NO}_{2} \mathrm{VCD} 1 \mathrm{~km}$ at the urban sites (Yokosuka and Gwangju) was pronounced in March to September when the $\mathrm{NO}_{2}$ TropVCD was low during the year (Figure 2). This result might have been caused by the active photolysis of $\mathrm{NO}_{2}$ around noon as summer approached, which was more emphasized by the relatively high accumulation of $\mathrm{NO}_{2}$ in the early morning. Compared to the weak second peak of the $\mathrm{NO}_{2} \mathrm{VCD} 1 \mathrm{~km}$ in the late afternoon in July and August in Yokosuka, that in Gwangju showed an obvious second peak in the afternoon (15:00 to 18:00 LST) because of rush hour, which was similar to that early in the morning because the site is close to a highway. In contrast, during the cold season (November-February), the MNB of the $\mathrm{NO}_{2}$ VCD1 $\mathrm{km}$ at the urban sites showed a different diurnal pattern in which the MNB increased in the early evening instead of in the early morning. High $\mathrm{NO}_{2} \mathrm{VCD} 1 \mathrm{~km}$ in the afternoon during the cold season has also been observed in many urban areas, such as Beijing [54] and Wuxi [55] in China and the Goddard Space Flight Center in the U.S. [56]. The accumulation of $\mathrm{NO}_{2}$ might result from its longer lifetime in winter due to the low $\mathrm{OH}$ concentration, which slowed the chemical loss, thus implying that NOx emissions may offset the chemical loss during the daylight hours [20,57]. However, rush hour peaks in the morning were not observed at the remote sites (Cape Hedo and Fukue) due to low local emissions from transportation.

Increasing $\mathrm{NO}_{2} \mathrm{VCD} 1 \mathrm{~km}$ in the afternoon is not common among the reported diurnal variations based on ground-level $\mathrm{NO}_{2}$ measurements. To analyse the ground-level $\mathrm{NO}_{2}$ along the direction of the line of sight for MAX-DOAS (to the north), the seasonal variation in $\mathrm{NO}_{2}$ measured from air quality monitoring stations, including the nearby Gwangju site (P1) and the north (P2-P4), was investigated (Figure S3). The hourly $\mathrm{NO}_{2}$ concentration (ppb) was monitored by a chemiluminescence instrument equipped with a molybdenum converter during the study period (2007-2017). The ground-level $\mathrm{NO}_{2}$ concentration was also high in winter and low in summer, which was similar to the $\mathrm{NO}_{2}$ TropVCD. However, the diurnal variation pattern in winter consisted of two peaks in the early morning and evening and a low concentration at 16:00 LT and was significantly different from that of the $\mathrm{NO}_{2} \mathrm{VCD} 1 \mathrm{~km}$. This different behaviour between the ground-level $\mathrm{NO}_{2}$ and $\mathrm{NO}_{2} \mathrm{VCD} 1 \mathrm{~km}$ was also observed in Yokosuka [20]. However, the converted volume mixing ratio from the $\mathrm{NO}_{2}$ TropVCD did not peak in the early evening in winter $[55,58]$. This feature could be explained by the diurnal variation in the planetary boundary layer height, which can systematically affect the diurnal patterns of ground-level $\mathrm{NO}_{2}$ but has almost no impact on the VCD1 km [55], and seasonal and/or diurnal variations in the surface temperature, pressure, and effective light path length, which are input parameters for the conversion of the volume mixing ratio [58]. 
(a) Yokosuka

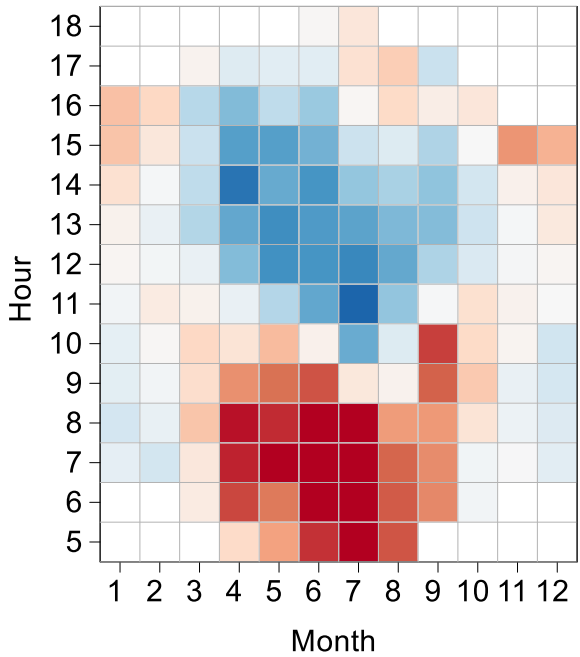

(c) Fukue

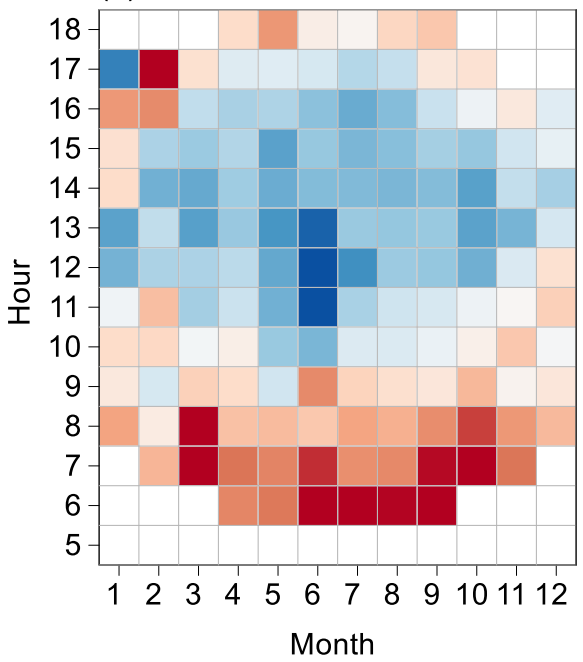

(b) Gwangju

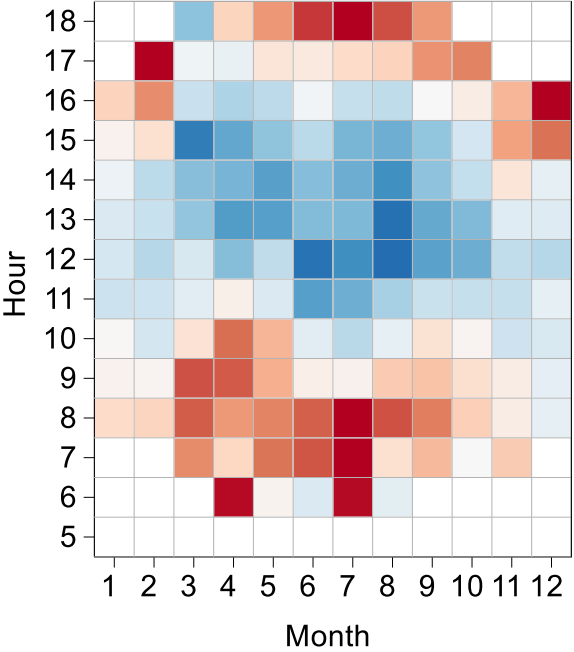

(d) Cape Hedo

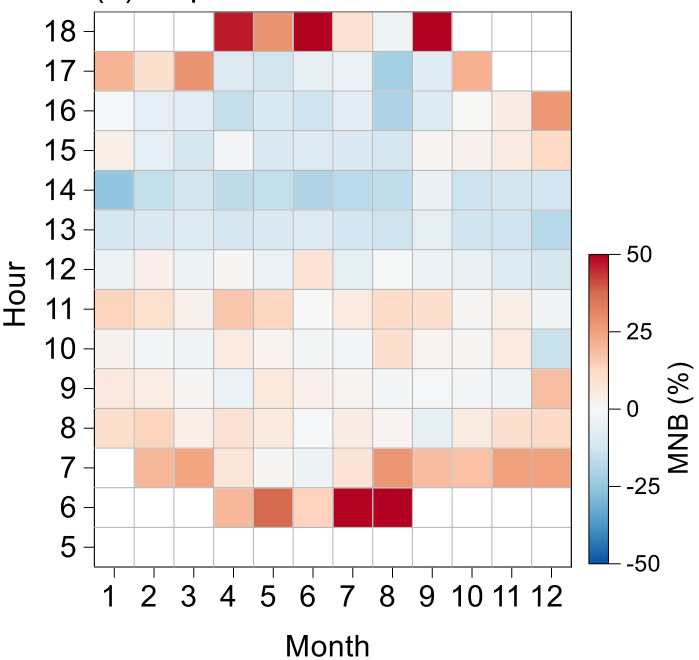

Figure 4. Monthly diurnal variation in the mean normalized bias (MNB) of $\mathrm{NO}_{2} \mathrm{VCD}$ at less than $1 \mathrm{~km}(\mathrm{VCD} 1 \mathrm{~km})$ at (a) Yokosuka, (b) Gwangju, (c) Fukue, and (d) Cape Hedo. The MNB is defined as $[\mathrm{A}-\mathrm{B}] / \mathrm{B} \times 100$, where $\mathrm{A}$ and $\mathrm{B}$ denote the hourly and daily mean $\mathrm{NO}_{2} \mathrm{VCD} 1 \mathrm{~km}$ from MAX-DOAS, respectively.

\subsection{Potential Source Region for the $\mathrm{NO}_{2}$ TropVCD at Yokosuka and Gwangju}

Figure 5 shows the seasonal potential source region of the $\mathrm{NO}_{2}$ TropVCD at Yokosuka and Gwangju. In winter, both sites were greatly affected by emissions over a relatively large area due to the long lifetime of $\mathrm{NO}_{2}$, whereas in the other seasons, both sites were dominated by local pollutants nearby. Regardless of the season, the hot spots for the $\mathrm{NO}_{2}$ TropVCD in Yokosuka were located in the Tokyo Bay area, which has the highest emission rate in the REAS emission inventory because of the large amount of emissions from the road transportation and industry sector, as described in the previous section. The identified potential source region based on the MAX-DOAS data showed good agreement with the spatial distribution of OMI satellite data, although OMI satellite simultaneously captures the spatial distribution of the $\mathrm{NO}_{2}$ TropVCD, which is a different definition of the potential source regions (Figure 6). This is because the Yokosuka site is located in the main hotspot area (Tokyo metropolitan area); therefore, the spatial distribution of the $\mathrm{NO}_{2}$ TropVCD from OMI and that of potential emission sources were well overlapped. 

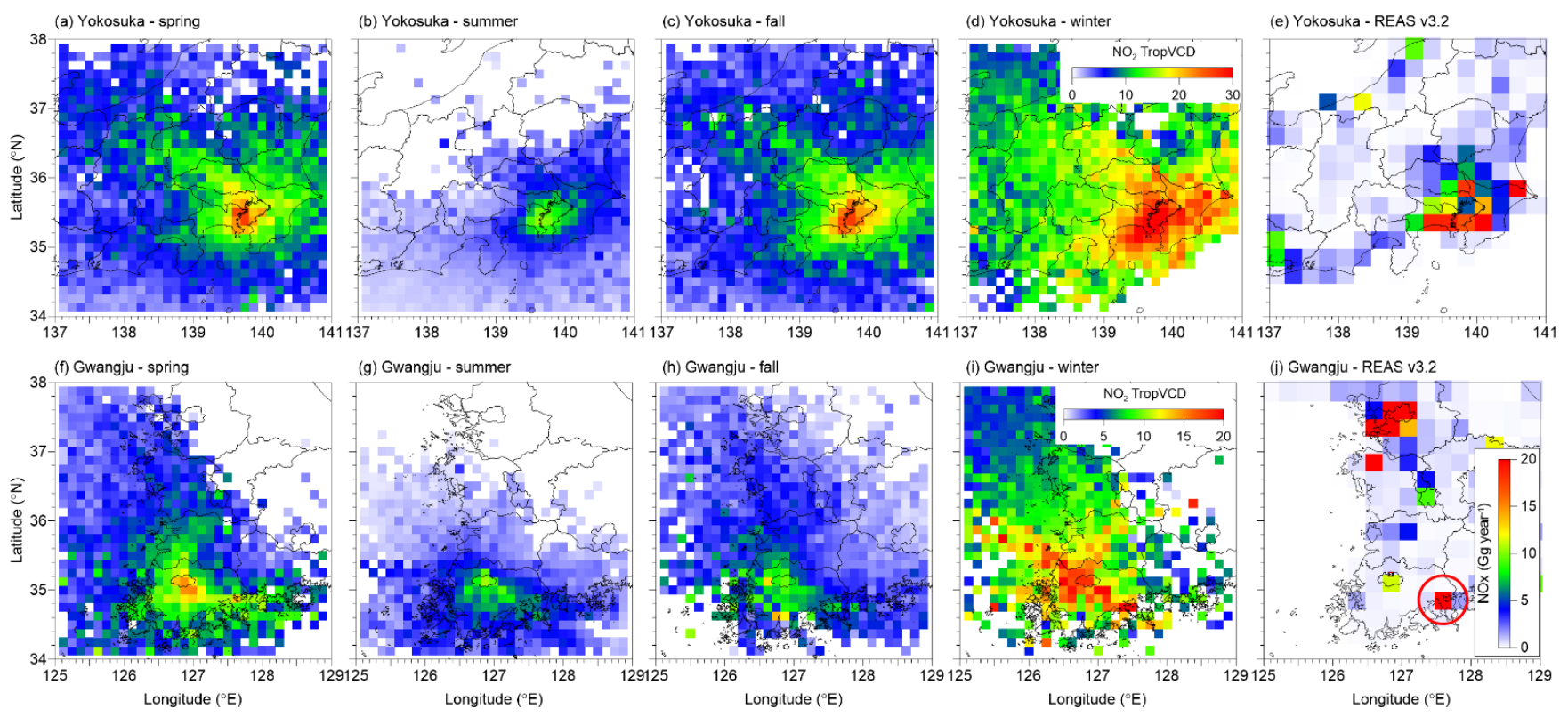

Figure 5. Seasonal spatial distribution of the potential source region of the $\mathrm{NO}_{2}$ TropVCD $\left(\times 10^{15}\right.$ molecules $\left.\mathrm{cm}^{-2}\right)$ at Yokosuka (a-d) and Gwangju (f-i) based on a combination of MAX-DOAS measurements and backward trajectories from the HYSPLIT model. The simulation time of the backward trajectories differed depending on the season (12 h in summer, $18 \mathrm{~h}$ for spring and fall, and $24 \mathrm{~h}$ for winter) by considering the doubling lifetime of $\mathrm{NO}_{2} \cdot \mathrm{NO}_{2}$ emission rates are from the REAS emission inventory version $3.2(\mathbf{e}, \mathbf{j})$. The red circle in $(\mathbf{j})$ indicates the Yeosu and Gwangyang National industrial complex.

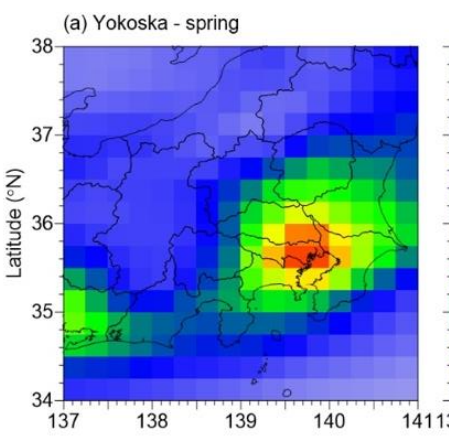

(b) Yokoska - summer

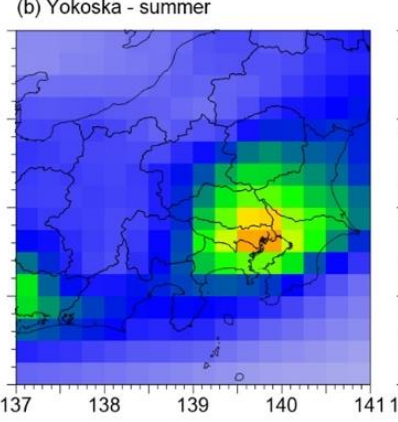

(c) Yokoska - fall

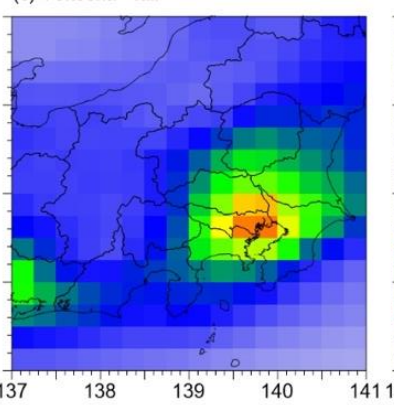

(d) Yokoska - winter

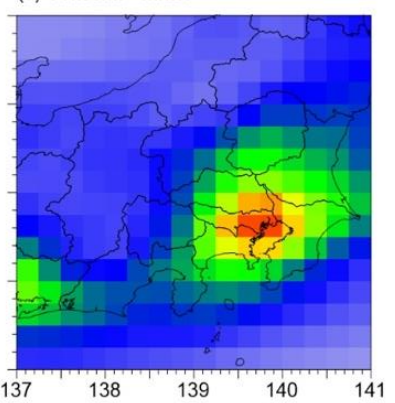

(g) Gwangiu - fall
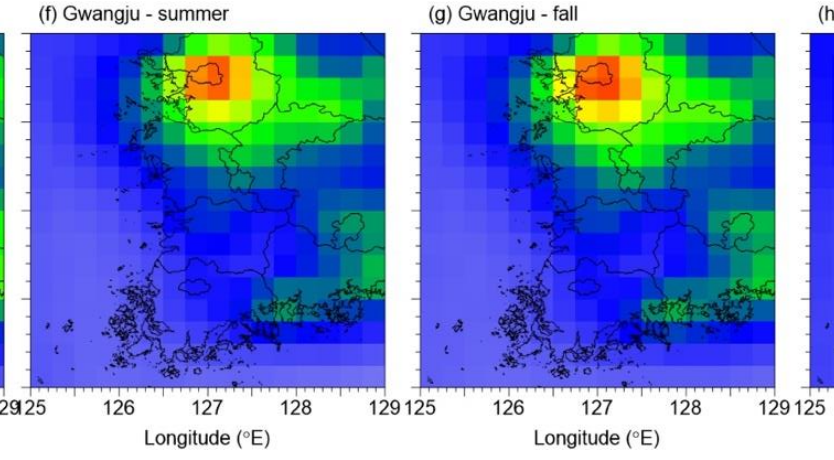

(h) Gwangju - winter

Longitude $\left({ }^{\circ} \mathrm{E}\right)$

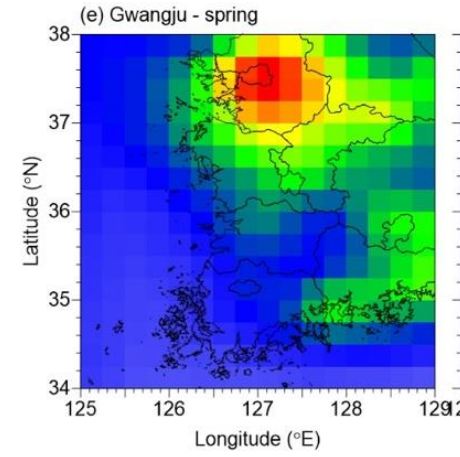

Figure 6. Seasonal distributions of $\mathrm{NO}_{2}$ TropVCD $\left(\times 10^{15}\right.$ molecules $\left.\mathrm{cm}^{-2}\right)$ at Yokosuka, Japan (a-d) and Gwangju, Korea (e-h) measured from Ozone Monitoring Instrument (OMI; OMNO2d) from 2007-2017.

Compared to that in Yokosuka, the seasonal potential source region in Gwangju had a different transport pattern that was influenced by the southern area in spring and winter and the local area in summer and fall. It should be noted that the hot spots in spring and winter were found at the National Industrial Complex in Yeosu $\left(127.67^{\circ} \mathrm{E}, 34.76^{\circ} \mathrm{N}\right)$ 
and Gwangyang $\left(127.77^{\circ} \mathrm{E}, 34.92^{\circ} \mathrm{N}\right)$, which are located approximately $80 \mathrm{~km}$ southwest of Gwangju and emitted a large amount of NOx based on the REAS emission inventory (red circle in Figure 5j). The NOx emission rates from Yeosu and Gwangyang from the Clean Air Policy Support System (CAPSS; $[59,60]$ ) were $69 \mathrm{Gg} \mathrm{yr}^{-1}$ (31 and $38 \mathrm{Gg} \mathrm{yr}^{-1}$, respectively), which is similar to that from Seoul $\left(77 \mathrm{Gg} \mathrm{yr}^{-1}\right)$ but much higher than that from Gwangju (10 Gg yr ${ }^{-1}$ ) (https: / / airemiss.nier.go.kr / (accessed on 31 August 2020)). Therefore, the $\mathrm{NO}_{2}$ emitted from the industrial complex had a continuous and significant effect on the air quality in Gwangju, but the magnitude could differ according to the $\mathrm{NO}_{2}$ lifetime (high in winter and low in summer). In addition, a large amount of $\mathrm{NO}_{2}$ was also observed in winter along the northwest direction, thus providing evidence of long-range transport from China, which explained the decreasing trend in wintertime, as discussed in Section 3.2. However, the spatial distribution of the $\mathrm{NO}_{2}$ TropVCD around Gwangju from OMI satellite data did not directly show that transport route. This might be caused by either different time resolutions (once a day for OMI vs. three times a day for potential source region) or relatively low OMI TropVCD in Gwangju $\left(4.4 \times 10^{15}\right.$ molecules cm $\left.{ }^{-2}\right)$, making the transport pathway easily masked by the uncertainty. It is concluded that our approach is suitable for identifying transportation routes from potential source areas that might not be recognized by satellite observations, especially in less polluted regions.

\section{Conclusions}

To enhance our understanding of the spatial and temporal (diurnal to long-term) variation of $\mathrm{NO}_{2}$, the $\mathrm{NO}_{2}$ TropVCDs from MAX-DOAS at four sites (Yokosuka, Fukue, and Cape Hedo in Japan and Gwangju in Korea) were investigated from 2007 to 2017 based on standardized retrieval processing and quality controls. The Theil-Sen slope of the long-term trend indicated a gradual reduction in $\mathrm{NO}_{2}$ at all Japanese sites, especially at Yokosuka, regardless of the season, whereas the $\mathrm{NO}_{2}$ TropVCD at Gwangju did not significantly change because $\mathrm{NO}_{2}$ was rapidly converted from $\mathrm{NO}$ and/or the oxidation state of the NOx emitted from diesel vehicles increased. The trends in Yokosuka and Gwangju were consistent with those in the ground-level $\mathrm{NO}_{2}$ concentrations measured at nearby air quality monitoring stations. A significant decrease in winter was observed in Gwangju, which was mainly due to long-range transport from China, whose emission rate has decreased since the 2010s. In contrast, at Fukue and Cape Hedo, the Theil-Sen slope for OMI data showed opposite trends (increased) to those observed for the MAX-DOAS $\mathrm{NO}_{2}$ TropVCD, suggesting that caution should be exercised when evaluating trends from satellite $\mathrm{NO}_{2}$ data for remote areas. The monthly mean of the $\mathrm{NO}_{2}$ TropVCD was lowest in summer and highest in winter, mainly due to the seasonal cycle of the $\mathrm{NO}_{2}$ lifetime. Importantly, the difference in the monthly $\mathrm{NO}_{2}$ TropVCD between the time-matched data and OMI ( 13:30 LT) and the whole data from MAX-DOAS implied active or inactive photochemical reactions according to the meteorological conditions. Regarding diurnal variations, double peaks in the early morning and afternoon in the urban areas (Yokosuka and Gwangju) were observed during summer due to active photochemical reactions along with high solar irradiance. However, the $\mathrm{NO}_{2} \mathrm{VCD} 1 \mathrm{~km}$ during the cold season peaked in the early evening instead of the early morning because of the longer $\mathrm{NO}_{2}$ lifetime resulting from less $\mathrm{NO}_{2}$ chemical loss. The identified potential source regions confirmed the emission hotspots in the REAS emission inventories: near the Tokyo metropolitan area for Yokosuka and near the Yeosu and Gwangyang National Industrial Complex for Gwangju. In the case of Yokosuka, which is close to the main emission region, the spatial distribution of OMI data was consistent with the potential source regions because Yokosuka is continuously influenced by the Tokyo metropolitan area. In contrast, the transport routes from Yeosu and Gwangyang to Gwangju were not clearly identified from OMI data, suggesting that our approach can provide more detailed information that might not be recognized by satellites, especially over less polluted regions. 
Supplementary Materials: The following are available online at https: / www.mdpi.com/article/ 10.3390/rs13101937/s1, Figure S1: Footprint of the total number of backward trajectory endpoints depending on the seasons at Gwangju, Korea, Figure S2: Long-term variations in the monthly mean ground-level $\mathrm{NO}_{2}$ from 2007 to 2017 at (a) Yokosuka and (b) Gwangju, Figure S3: Site location and diurnal variation of ground $\mathrm{NO}_{2}$ concentrations from air quality monitoring stations (P1 to P4) by season. Table S1: Observed seasonal and overall Theil-Sen slopes of tropospheric $\mathrm{NO}_{2}$ vertical column density from MAX-DOAS whole data points at four sites and ground $\mathrm{NO}_{2}$ concentration $(\mathrm{ppb})$ from air quality monitoring station at Yokosuka and Gwangju from 2007-2017.

Author Contributions: Y.C. and Y.K. designed the study and prepared the paper, with contributions from all coauthors. H.T. and H.I. conducted measurements at Yokosuka, Fukue, and Cape Hedo. K.P. and J.C. were responsible for the measurements at Gwangju. All authors have read and agreed to the published version of the manuscript.

Funding: This research was supported by the GOSAT-GW NO2 NIES-JAMSTEC-NICT collaborative research project.

Data Availability Statement: The MAX-DOAS data files for the MADRAS network observations from 2007 to 2019 are available at http:/ / ebcrpa.jamstec.go.jp/maxdoashp (accessed on 20 December 2020). The data for other periods can be provided upon request. The ground-level $\mathrm{NO}_{2}$ concentrations in Yokohama and Gwangju are available at https:/ / www.city.yokohama.lg.jp/kurashi/machizukurikankyo/kankyohozen/kansoku/kanshi_center/geppo/geppoarc.html (in Japanese) (accessed on 19 April 2021) and https:/ / www.airkorea.or.kr/web/last_amb_hour_data?pMENU_NO=123 (in Korean) (accessed on 19 April 2021), respectively.

Acknowledgments: The authors thank NOAA ARL and ECMWF for providing the HYSPLIT model and ERA5 meteorological data. Additionally, we thank the City of Yokohama and the National Institute of Environmental Research (NIER) for maintaining the air quality monitoring stations used in this study.

Conflicts of Interest: The authors declare that they have no conflicts of interest.

\section{References}

1. Bond, D.W.; Zhang, R.; Tie, X.; Brasseur, G.P.; Huffines, G.R.; Orville, R.E.; Boccippio, D.J. NOxproduction by lightning over the continental United States. J. Geophys. Res. Space Phys. 2001, 106, 27701-27710. [CrossRef]

2. Zhang, R.; Tie, X.; Bond, D.W. Impacts of anthropogenic and natural NOx sources over the U.S. on tropospheric chemistry. Proc. Natl. Acad. Sci. USA 2003, 100, 1505-1509. [CrossRef]

3. Crutzen, P.J. The influence of nitrogen oxides on the atmospheric ozone content. Q. J. R. Meteorol. Soc. 1970, 96, 320-325. [CrossRef]

4. Leighton, P. Photochemistry of Air Pollution; Elsevier: Amsterdam, The Netherlands, 2012.

5. Finlayson-Pitts, B.J.; Pitts, J.N., Jr. Atmospheric Chemistry. Fundamentals and Experimental Techniques. Available online: https: //www.osti.gov/biblio/6379212-atmospheric-chemistry-fundamentals-experimental-techniques (accessed on 13 May 2021).

6. Zhao, B.; Wang, S.X.; Liu, H.; Xu, J.Y.; Fu, K.; Klimont, Z.; Hao, J.M.; He, K.B.; Cofala, J.; Amann, M.C. NOx emissions in China: Historical trends and future perspectives. Atmos. Chem. Phys. 2013, 13, 9869-9897. [CrossRef]

7. Zhang, Q.; Streets, D.G.; He, K.; Wang, Y.; Richter, A.; Burrows, J.P.; Uno, I.; Jang, C.J.; Chen, D.; Yao, Z.; et al. NOxemission trends for China, 1995-2004: The view from the ground and the view from space. J. Geophys. Res. Space Phys. 2007, 112. [CrossRef]

8. Liu, F.; Zhang, Q.; van der Ronald, J.A.; Zheng, B.; Tong, D.; Yan, L.; Zheng, Y.; He, K. Recent reduction in NO x emissions over China: Synthesis of satellite observations and emission inventories. Environ. Res. Lett. 2016, 11, 114002. [CrossRef]

9. Georgoulias, A.K.; van der Ronald, J.A.; Stammes, P.; Boersma, K.F.; Eskes, H.J. Trends and trend reversal detection in 2 decades of tropospheric NO2 satellite observations. Atmos. Chem. Phys. 2019, 19, 6269-6294. [CrossRef]

10. Jamali, S.; Klingmyr, D.; Tagesson, T. Global-Scale Patterns and Trends in Tropospheric $\mathrm{NO}_{2}$ Concentrations, 2005-2018. Remote Sens. 2020, 12, 3526. [CrossRef]

11. Zheng, B.; Tong, D.; Li, M.; Liu, F.; Hong, C.; Geng, G.; Li, H.; Li, X.; Peng, L.; Qi, J.; et al. Trends in China's anthropogenic emissions since 2010 as the consequence of clean air actions. Atmos. Chem. Phys. 2018, 18, 14095-14111. [CrossRef]

12. Kurokawa, J.; Ohara, T. Long-term historical trends in air pollutant emissions in Asia: Regional Emission inventory in ASia (REAS) version 3. Atmos. Chem. Phys. 2020, 20, 12761-12793. [CrossRef]

13. Heckel, A.; Richter, A.; Tarsu, T.; Wittrock, F.; Hak, C.; Pundt, I.; Junkermann, W.; Burrows, J.P. MAX-DOAS measurements of formaldehyde in the Po-Valley. Atmos. Chem. Phys. 2005, 5, 909-918. [CrossRef]

14. Hönninger, G.; Von Friedeburg, C.; Platt, U. Multi axis differential optical absorption spectroscopy (MAX-DOAS). Atmos. Chem. Phys. 2004, 4, 231-254. [CrossRef] 
15. Pinardi, G.; Van Roozendael, M.; Abuhassan, N.; Adams, C.; Cede, A.; Clémer, K.; Fayt, C.; Frieß, U.; Gil, M.; Herman, J.; et al. MAX-DOAS formaldehyde slant column measurements during CINDI: Intercomparison and analysis improvement. Atmos. Meas. Tech. 2012, 6, 167-185. [CrossRef]

16. Kreher, K.; Van Roozendael, M.; Hendrick, F.; Apituley, A.; Dimitropoulou, E.; Frieß, U.; Richter, A.; Wagner, T.; Lampel, J.; Abuhassan, $\mathrm{N}$.; et al. Intercomparison of $\mathrm{NO} 2, \mathrm{O} 4, \mathrm{O} 3$ and $\mathrm{HCHO}$ slant column measurements by MAX-DOAS and zenith-sky UV-visible spectrometers during CINDI-2. Atmos. Meas. Tech. 2020, 13, 2169-2208. [CrossRef]

17. Drosoglou, T.; Koukouli, M.E.; Kouremeti, N.; Bais, A.F.; Zyrichidou, I.; Balis, D.; van der Ronald, J.A.; Xu, J.; Li, A. MAX-DOAS NO2 observations over Guangzhou, China; ground-based and satellite comparisons. Atmos. Meas. Tech. 2018, 11, $2239-2255$. [CrossRef]

18. Irie, H.; Boersma, K.F.; Kanaya, Y.; Takashima, H.; Pan, X.; Wang, Z.F. Quantitative bias estimates for tropospheric NO2 columns retrieved from SCIAMACHY, OMI, and GOME-2 using a common standard for East Asia. Atmos. Meas. Tech. 2012, 5, $2403-2411$. [CrossRef]

19. Chan, K.L.; Wang, Z.; Ding, A.; Heue, K.-P.; Shen, Y.; Wang, J.; Zhang, F.; Shi, Y.; Hao, N.; Wenig, M. MAX-DOAS measurements of tropospheric $\mathrm{NO} 2$ and $\mathrm{HCHO}$ in Nanjing and a comparison to ozone monitoring instrument observations. Atmos. Chem. Phys. 2019, 19, 10051-10071. [CrossRef]

20. Kanaya, Y.; Irie, H.; Takashima, H.; Iwabuchi, H.; Akimoto, H.; Sudo, K.; Gu, M.; Chong, J.; Kim, Y.J.; Lee, H.; et al. Long-term MAX-DOAS network observations of NO2 in Russia and Asia (MADRAS) during the period 2007-2012: Instrumentation, elucidation of climatology, and comparisons with OMI satellite observations and global model simulations. Atmos. Chem. Phys. 2014, 14, 7909-7927. [CrossRef]

21. Li, X.; Brauers, T.; Hofzumahaus, A.; Lu, K.; Li, Y.P.; Shao, M.; Wagner, T.; Wahner, A. MAX-DOAS measurements of NO2, HCHO and $\mathrm{CHOCHO}$ at a rural site in Southern China. Atmos. Chem. Phys. 2013, 13, 2133-2151. [CrossRef]

22. Irie, H.; Hoque, H.M.S.; Damiani, A.; Okamoto, H.; Fatmi, A.M.; Khatri, P.; Takamura, T.; Jarupongsakul, T. Simultaneous observations by sky radiometer and MAX-DOAS for characterization of biomass burning plumes in central Thailand in JanuaryApril 2016. Atmos. Meas. Tech. 2019, 12, 599-606. [CrossRef]

23. Kanaya, Y.; Yamaji, K.; Miyakawa, T.; Taketani, F.; Zhu, C.; Choi, Y.; Komazaki, Y.; Ikeda, K.; Kondo, Y.; Klimont, Z. Rapid reduction in black carbon emissions from China: Evidence from 2009-2019 observations on Fukue Island, Japan. Atmos. Chem. Phys. 2020, 20, 6339-6356. [CrossRef]

24. Kanaya, Y.; Pan, X.; Miyakawa, T.; Komazaki, Y.; Taketani, F.; Uno, I.; Kondo, Y. Long-term observations of black carbon mass concentrations at Fukue Island, western Japan, during 2009-2015: Constraining wet removal rates and emission strengths from East Asia. Atmos. Chem. Phys. 2016, 16, 10689-10705. [CrossRef]

25. Miyakawa, T.; Komazaki, Y.; Zhu, C.; Taketani, F.; Pan, X.; Wang, Z.; Kanaya, Y. Characterization of carbonaceous aerosols in Asian outflow in the spring of 2015: Importance of non-fossil fuel sources. Atmos. Environ. 2019, 214, 116858. [CrossRef]

26. Miyakawa, T.; Oshima, N.; Taketani, F.; Komazaki, Y.; Yoshino, A.; Takami, A.; Kondo, Y.; Kanaya, Y. Alteration of the size distributions and mixing states of black carbon through transport in the boundary layer in east Asia. Atmos. Chem. Phys. 2017, 17, 5851-5864. [CrossRef]

27. Takashima, H.; Irie, H.; Kanaya, Y.; Akimoto, H. Enhanced NO2 at Okinawa Island, Japan caused by rapid air-mass transport from China as observed by MAX-DOAS. Atmos. Environ. 2011, 45, 2593-2597. [CrossRef]

28. Rodgers, C.D. Inverse Methods for Atmospheric Sounding. Available online: https://www.worldscientific.com/worldscibooks/ 10.1142/3171 (accessed on 13 May 2021).

29. Chance, K.V.; Spurr, R.J.D. Ring effect studies: Rayleigh scattering, including molecular parameters for rotational Raman scattering, and the Fraunhofer spectrum. Appl. Opt. 1997, 36, 5224-5230. [CrossRef]

30. Hermans, C.; Vandaele, A.C.; Fally, S.; Carleer, M.; Colin, R.; Coquart, B.; Jenouvrier, A.; Merienne, M.-F. Absorption Cross-section of the Collision-Induced Bands of Oxygen from the UV to the NIR. In Weakly Interacting Molecular Pairs: Unconventional Absorbers of Radiation in the Atmosphere; Springer: Berlin/Heidelberg, Germany, 2003; pp. 193-202.

31. Wagner, T.; Beirle, S.; Benavent, N.; Bösch, T.; Chan, K.L.; Donner, S.; Dörner, S.; Fayt, C.; Frieß, U.; García-Nieto, D.; et al. Is a scaling factor required to obtain closure between measured and modelled atmospheric $\mathrm{O} 4$ absorptions? An assessment of uncertainties of measurements and radiative transfer simulations for 2 selected days during the MAD-CAT campaign. Atmos. Meas. Tech. 2019, 12, 2745-2817. [CrossRef]

32. Vandaele, A.C.; Hermans, C.; Simon, P.C.; Van Roozendael, M.; Guilmot, J.M.; Carleer, M.; Colin, R. Fourier transform measurement of NO2 absorption cross-section in the visible range at room temperature. J. Atmos. Chem. 1996, 25, 289-305. [CrossRef]

33. Bogumil, K.; Orphal, J.; Homann, T.; Voigt, S.; Spietz, P.; Fleischmann, O.; Vogel, A.; Hartmann, M.; Kromminga, H.; Bovensmann, H.; et al. Measurements of molecular absorption spectra with the SCIAMACHY pre-flight model: Instrument characterization and reference data for atmospheric remote-sensing in the 230-2380 nm region. J. Photochem. Photobiol. A Chem. 2003, 157, 167-184. [CrossRef]

34. Rothman, L.; Barbe, A.; Benner, D.C.; Brown, L.; Camy-Peyret, C.; Carleer, M.; Chance, K.; Clerbaux, C.; Dana, V.; Devi, V.; et al. The HITRAN molecular spectroscopic database: Edition of 2000 including updates through 2001. J. Quant. Spectrosc. Radiat. Transf. 2003, 82, 5-44. [CrossRef]

35. Iwabuchi, H. Efficient Monte Carlo Methods for Radiative Transfer Modeling. J. Atmos. Sci. 2006, 63, 2324-2339. [CrossRef] 
36. Takashima, H.; Irie, H.; Kanaya, Y.; Shimizu, A.; Aoki, K.; Akimoto, H. Atmospheric aerosol variations at Okinawa Island in Japan observed by MAX-DOAS using a new cloud-screening method. J. Geophys. Res. Space Phys. 2009, 114, D18. [CrossRef]

37. Irie, H.; Takashima, H.; Kanaya, Y.; Boersma, K.F.; Gast, L.F.L.; Wittrock, F.; Brunner, D.; Zhou, Y.; Van Roozendael, M. Eightcomponent retrievals from ground-based MAX-DOAS observations. Atmos. Meas. Tech. 2011, 4, 1027-1044. [CrossRef]

38. Irie, H.; Kanaya, Y.; Akimoto, H.; Iwabuchi, H.; Shimizu, A.; Aoki, K. First retrieval of tropospheric aerosol profiles using MAX-DOAS and comparison with lidar and sky radiometer measurements. Atmos. Chem. Phys. 2008, 8, 341-350. [CrossRef]

39. Takashima, H.; Irie, H.; Kanaya, Y.; Syamsudin, F. NO2 observations over the western Pacific and Indian Ocean by MAX-DOAS on Kaiyo, a Japanese research vessel. Atmos. Meas. Tech. 2012, 5, 2351-2360. [CrossRef]

40. Krotkov, N.A.; Lamsal, L.N.; Celarier, E.A.; Swartz, W.H.; Marchenko, S.V.; Bucsela, E.J.; Chan, K.L.; Wenig, M.; Zara, M. The version 3 OMI NO2 standard product. Atmos. Meas. Tech. 2017, 10, 3133-3149. [CrossRef]

41. Marchenko, S.V.; A Krotkov, N.; Lamsal, L.N.; Celarier, E.; Swartz, W.H.; Bucsela, E.J. Revising the slant column density retrieval of nitrogen dioxide observed by the Ozone Monitoring Instrument. J. Geophys. Res. Atmos. 2015, 120, 5670-5692. [CrossRef]

42. Strahan, S.E.; Duncan, B.N.; Hoor, P. Observationally derived transport diagnostics for the lowermost stratosphere and their application to the GMI chemistry and transport model. Atmos. Chem. Phys. 2007, 7, 2435-2445. [CrossRef]

43. Draxler, R.; Stunder, B.; Rolph, G.; Stein, A.; Taylor, A. HYSPLIT4 User's Guide; Version 4-Last Revision: February 2018; HYSPLIT Air Resources Laboratory: College Park, MD, USA, 2018.

44. Lee, H.-J.; Kim, S.-W.; Brioude, J.; Cooper, O.R.; Frost, G.J.; Kim, C.-H.; Park, R.; Trainer, M.; Woo, J.-H. Transport of NOxin East Asia identified by satellite and in situ measurements and Lagrangian particle dispersion model simulations. J. Geophys. Res. Atmos. 2014, 119, 2574-2596. [CrossRef]

45. Wang, Y.; Dörner, S.; Donner, S.; Böhnke, S.; De Smedt, I.; Dickerson, R.R.; Dong, Z.; He, H.; Li, Z.; Li, Z.; et al. Vertical profiles of $\mathrm{NO} 2, \mathrm{SO} 2, \mathrm{HONO}, \mathrm{HCHO}, \mathrm{CHOCHO}$ and aerosols derived from MAX-DOAS measurements at a rural site in the central western North China Plain and their relation to emission sources and effects of regional transport. Atmos. Chem. Phys. 2019, 19, 5417-5449. [CrossRef]

46. Xu, W.; Zhao, C.; Ran, L.; Deng, Z.; Ma, N.; Liu, P.; Lin, W.; Yan, P.; Xu, X. A new approach to estimate pollutant emissions based on trajectory modeling and its application in the North China Plain. Atmos. Environ. 2013, 71, 75-83. [CrossRef]

47. Theil, H. A rank-invariant method of linear and polynomial regression analysis. I, II, III. Proc. K. Ned. Akademie Wet. 1950, 53, 386-392, 521-525, 1397-1412.

48. Sen, P.K. Estimates of the regression coefficient based on Kendall's tau. J. Am. Stat. Assoc. 1968, 63, 1379-1389. [CrossRef]

49. Carslaw, D.C.; Ropkins, K. Openair-An R package for air quality data analysis. Environ. Model. Softw. 2012, 27-28, 52-61. [CrossRef]

50. Duncan, B.N.; Lamsal, L.N.; Thompson, A.M.; Yoshida, Y.; Lu, Z.; Streets, D.G.; Hurwitz, M.M.; Pickering, K.E. A space-based, high-resolution view of notable changes in urban NOx pollution around the world (2005-2014). J. Geophys. Res. Atmos. 2016, 121, 976-996. [CrossRef]

51. Wakamatsu, S.; Morikawa, T.; Ito, A. Air pollution trends in Japan between 1970 and 2012 and impact of urban air pollution countermeasures. Asian J. Atmos. Environ. 2013, 7, 177-190. [CrossRef]

52. Herman, J.; Spinei, E.; Fried, A.; Kim, J.; Kim, J.; Kim, W.; Cede, A.; Abuhassan, N.; Segal-Rozenhaimer, M. NO2 and HCHO measurements in Korea from 2012 to 2016 from Pandora spectrometer instruments compared with OMI retrievals and with aircraft measurements during the KORUS-AQ campaign. Atmos. Meas. Tech. 2018, 11, 4583-4603. [CrossRef]

53. Kim, Y.P.; Lee, G. Trend of Air Quality in Seoul: Policy and Science. Aerosol Air Qual. Res. 2018, 18, 2141-2156. [CrossRef]

54. Ma, J.Z.; Beirle, S.; Jin, J.L.; Shaiganfar, R.; Yan, P.; Wagner, T. Tropospheric NO2 vertical column densities over Beijing: Results of the first three years of ground-based MAX-DOAS measurements (2008-2011) and satellite validation. Atmos. Chem. Phys. 2013, 13, 1547-1567. [CrossRef]

55. Wang, Y.; Lampel, J.; Xie, P.; Beirle, S.; Li, A.; Wu, D.; Wagner, T. Ground-based MAX-DOAS observations of tropospheric aerosols, NO2, SO2 and HCHO in Wuxi, China, from 2011 to 2014. Atmos. Chem. Phys. 2017, 17, 2189-2215. [CrossRef]

56. Wenig, M.O.; Cede, A.M.; Bucsela, E.J.; Celarier, E.A.; Boersma, K.F.; Veefkind, J.P.; Brinksma, E.J.; Gleason, J.F.; Herman, J.R. Validation of OMI tropospheric NO2column densities using direct-Sun mode Brewer measurements at NASA Goddard Space Flight Center. J. Geophys. Res. Space Phys. 2008, 113. [CrossRef]

57. Boersma, K.F.; Jacob, D.J.; Trainic, M.; Rudich, Y.; Desmedt, I.; Dirksen, R.; Eskes, H.J. Validation of urban NO2 concentrations and their diurnal and seasonal variations observed from the SCIAMACHY and OMI sensors using in situ surface measurements in Israeli cities. Atmos. Chem. Phys. 2009, 9, 3867-3879. [CrossRef]

58. Schreier, S.F.; Richter, A.; Peters, E.; Ostendorf, M.; Schmalwieser, A.W.; Weihs, P.; Burrows, J.P. Dual ground-based MAXDOAS observations in Vienna, Austria: Evaluation of horizontal and temporal NO2, HCHO, and CHOCHO distributions and comparison with independent data sets. Atmos. Environ. X 2020, 5, 100059. [CrossRef]

59. Lee, D.-G.; Lee, Y.-M.; Jang, K.-W.; Yoo, C.; Kang, K.-H.; Lee, J.-H.; Jung, S.-W.; Park, J.-M.; Lee, S.-B.; Han, J.-S.; et al. Korean National Emissions Inventory System and 2007 Air Pollutant Emissions. Asian J. Atmos. Environ. 2011, 5, 278-291. [CrossRef]

60. Yeo, S.-Y.; Lee, H.-K.; Choi, S.-W.; Seol, S.-H.; Jin, H.-A.; Yoo, C.; Lim, J.-Y.; Kim, J.-S.; Hyang-Kyeong, L. Analysis of the National Air Pollutant Emission Inventory (CAPSS 2015) and the Major Cause of Change in Republic of Korea. Asian J. Atmos. Environ. 2019, 13, 212-231. [CrossRef] 